\title{
KLASIFIKASI FERTILITAS TELUR ITIK DENGAN PENGOLAHAN CITRA DIGITAL MENGGUNAKAN RASPBERRY PI
}

\author{
${ }^{1}$ Jamaludin Indra, ${ }^{2}$ Nazori Agani, ${ }^{3}$ Hanny Hikmayanti Handayani \\ 1 jamaludin.indra@ubpkarawang.ac.id , ${ }^{2}$ nazori.agani@gmail.com , ${ }^{3}$ \\ hanny.hikmayanti@ubpkarawang.ac.id \\ ${ }^{1,3}$ Universitas Buana Perjuangan Karawang, Teknik Informatika Jl. HS.Ronggo Waluyo, Timur, \\ Karawang, Jawa Barat 41361 \\ ${ }^{2}$ Program Studi Magister Ilmu Komputer, Program Pascasarjana, Universitas Budi Luhur \\ Jl. Raya Ciledug, Petukangan Utara, Kebayoran Lama, Jakarta Selatan 12260
}

\begin{abstract}
ABSTRAK
Pengklasifikasian embrio telur menjadi sangat penting dalam proses penetasan untuk membedakan antara yang layak; berdasarkan adanya perkembangan embrio yang dapat dilanjutkan dalam proses inkubasi atau tidak layak (fertil atau infertil). Penelitian ini menyajikan deteksi dengan teknik pengolahan citra digital dan menggunakan komputer kecil yaitu Raspberry Pi sebagai pemroses gambar dan menampilkan hasil klasifikasi. Dengan metode dan penggunaan Raspberry Pi akurasi pendeteksian mencapai $90 \%$ dan $95 \%$.
\end{abstract}

Kata kunci: Raspberry Pi, Pengolahan Citra Digital, Embrio, Klasifikasi, Telur

\section{PENDAHULUAN}

Saat ini pengolahan citra digital telah menggunakan Raspberry Pi sebagai pengolah datanya. Penelitian sebelumnya adalah pengambilan gambar sistem tertanam menggunakan Raspberry Pi dengan metode eigen faces dan face recognition untuk menemukan persamaan, hasilnya membuktikan bahwa sistem tertanam menggunakan Raspberry Pi lebih kecil dimensinya, konsumsi listrik yang rendah dan mampu mengolah data dan lebih mudah daripada PC-berbasis face recognition (Senthilkumar, Gopalakrishnan and Kumar, 2014). Penelitian lain yaitu implementasi pengolahan citra digital pada Raspberry pi dengan metode citra digital untuk mengolah gambar, dengan menggunakan algoritma untuk meningkatkan kualitas gambar Raspberry Pi berhasil mengeksekusi dan mengolah gambar yang berwarna-warni dan berkualitas (Shilpashree, Lokesha and Shivkumar, 2015).

Penerapan pengolahan citra digital menggunakan Raspberry pi akan diaplikasikan dalam klasifikasi fertilitas telur itik, dimana penelitian sebelumnya telah ada yang menerapkan pengolahan citra digital untuk pendeteksian telur. Pendeteksian embrio telur ayam berdasarkan citra greyscale menggunakan metode k-means automatic thresholding di MATLAB, dengan metode otsu untuk menentukan nilai threshold dikarenakan metode otsu threshold lebih baik hasilnya dibandingkan dengan metode iterative threshold (Holambe and Kumbhar, 2016). Teknik citra digital digunakan untuk mengklasifikasi besar telur dan kotoran telur menghasilkan akurasi 80 - 90

$\%$ (Ibrahim et al., 2012).

Berdasarkan penelitian-penelitian diatas bahwa Raspberry Pi bisa diaplikasikan untuk mengolah data citra digital yang akan diaplikasikan pada deteksi embrio telur itik dengan metode teknik pengolahan citra digital mengklasifikasikan telur fertil dan infertil berdasarkan citra greyscale-nya.

\section{LANDASAN TEORI}

\section{A. Raspberry Pi}

Raspberry Pi atau sering juga disingkat dengan nama Raspi merupakan sebuah komputer papan tunggal (Single Board Circuit / SBC) berukuran mini sebesar kartu kredit. 


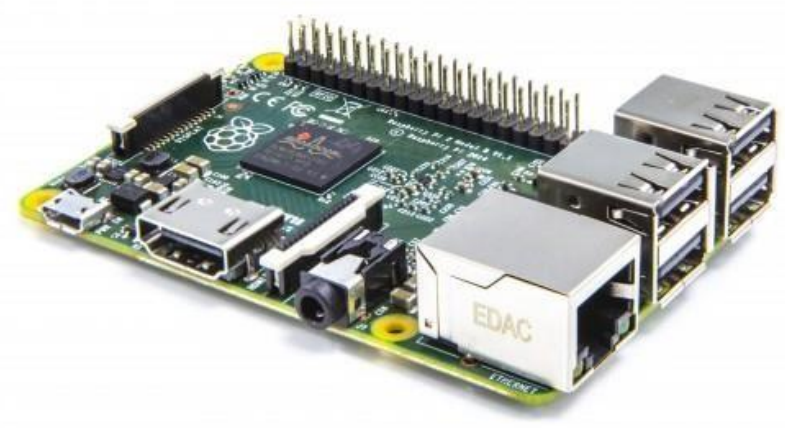

Gambar 2. 1: Papan Raspberry Pi

Raspberry Pi biasa digunakan untuk berbagai keperluan seperti spreadsheet, game, bahkan biasa digunakan sebagai media player karena kemampuannya dalam memutar video high definition(Senthilkumar, Gopalakrishnan and Kumar, 2014).

\section{B. Sistem Operasi Raspbian}

Raspbian adalah sistem operasi bebas berbasis Linux Debian dioptimalkan untuk perangkat keras Raspberry Pi. Sistem operasi adalah seperangkat program dasar dan utilitas yang membuat Anda Raspberry Pi beroperasi. Namun, Raspbian menyediakan lebih dari OS murni, Raspberry Pi datang dengan lebih dari 35.000 paket, software pre-compiled dibundel dalam format yang bagus untuk kemudahan instalasi pada Raspberry Pi.

\section{Python}

Python merupakan Bahasa pemrograman interaktif, multiguna berorientasi objek. Python menyediakan struktur data tingkat tinggi seperti daftar dan associative arrays, pengetikan yang dinamis, dynamic binding, modul, class, exceptions, manajemen memori otomatis, dan yang lainnya. Python memiliki sintak yang sangat sederhana dan elegan, namun python adalah bahasa pemrograman yang handal dan umum. Python dirancang pada tahun 1990 oleh Guido van Rossum. Seperti banyak Bahasa pemrograman script yang lainnya python bersifat gratis, bahkan untuk kebutuhan komersial, dan biasa di jalankan dihampir semua komputer modern saat ini.

\section{Pustaka OpenCV}

OpenCV (Open Source Computer Vision Library) adalah sebuah pustaka perangkat lunak yang ditujukan untuk pengolahan citra dinamis secara real-time, yang dibuat oleh Intel, dan sekarang didukung oleh Willow Garage dan Itseez. Program ini bebas dan berada dalam naungan sumber terbuka dari lisensi BSD. Pustaka ini merupakan pustaka lintas platform. Program ini didedikasikan sebagian besar untuk pengolahan citra secara real- time. Jika pustaka ini menemukan pustaka Integrated Performance Primitives dari intel dalam sistem komputer, maka program ini akan menggunakannya secara rutin untuk mempercepat proses kerja program ini secara otomatis.

OpenCV pertama kali diluncurkan secara resmi pada tahun 1999 oleh Intel Research sebagai lanjutan dari bagian proyek bertajuk aplikasi intensif berbasis CPU, real-time ray tracing dan penampil 3D. Para kontributor utama dalam proyek ini termasuk mereka yang berkecimpung dalam bidang optimasi di Intel Rusia, dan juga Tim Pustaka Performansi Intel.

\section{E. Pengolahan Citra Digital}

Pengolahan citra digital dapat didefinisikan sebagai ilmu memodifikasi gambar digital dengan menggunakan komputer. Perubahan yang terjadi dalam gambar biasanya dilakukan secara otomatis dan mengandalkan algoritma yang dirancang dengan hati-hati . pada proses manual keberhasilan tergantung dari kemampuan dan keahlian manusia tersebut.

Pengolahan citra digital merupakan bidang multi disiplin, dengan kontribusi dari berbagai cabang ilmu pengetahuan (terutama matematika, fisika dan ilmu komputer) dan komputer, optik dan teknik listrik. Dan selain itu bersinggungan dengan disiplin lain yaitu pattern recognition, machine learning, artificial intelligence dan penelitian penglihatan manusia.

\section{F. Kerangka Konsep Pemikiran}

Masalah yang diangkat pada penelitian ini adalah bagaimana membuat alat yang murah dan mampu untuk mensegmentasi dan mendeteksi embrio telur itik sehingga mempermudah proses pendeteksian embrio telur itik. 


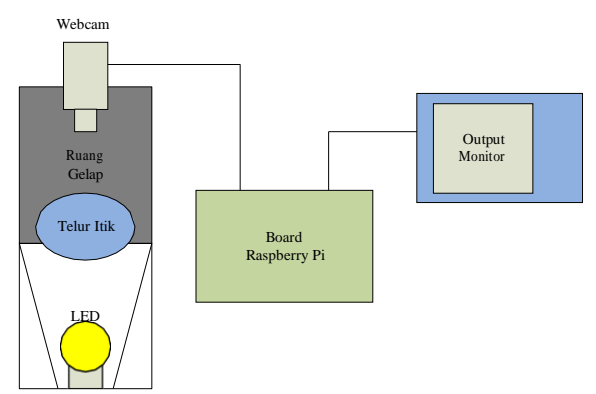

Gambar 2. 2: Alur diagram pengambilan citra

Gambar 2.2 menggambarkan bagaimana alur proses pengambilan citra telur diambil menggunakan perangkat optik yaitu camera $\mathrm{Pi}$, selanjutnya gambar tersebut diproses oleh komputer mini Raspberry $\mathrm{Pi}$, hasil dari pengolahan citra digital akan ditampilkan menggunakan monitor.

\section{METODE PENELITIAN}

\section{A. Kerangka Kerja Perangkat Keras}

Pada Gambar 3 menunjukan alur proses dan perangkat yang digunakan, proses awal yaitu Raspberry Pi aktif dan menjalankan aplikasi deteksi telur untuk mulai mengambil video dari camera Pi .telur di tempatkan pada ruang yang gelap, karena untuk menghasilkan gambar yang baik dalam pengambilan gambar telur harus berlatar belakang gelap (Zhu and Ma, 2011). Proses selanjutnya LED akan aktif untuk pencahayaan, setelah itu gambar akan diambil dan diproses oleh Raspberry $\mathrm{Pi}$, hasilnya akan di tampilkan di monitor.

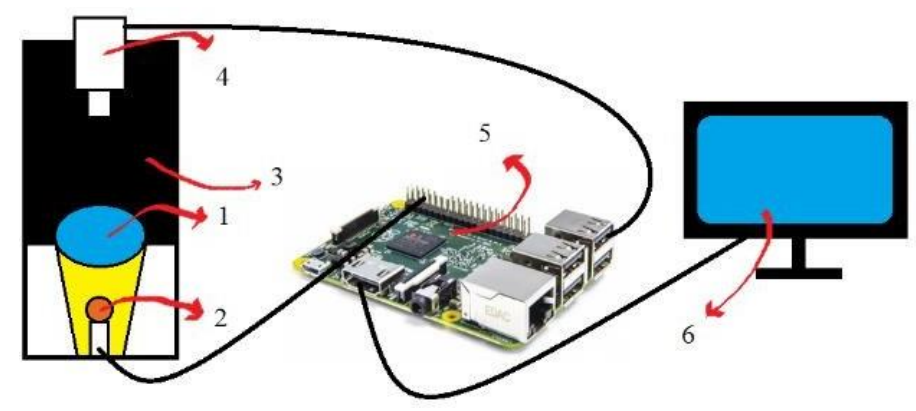

Gambar 3. 1: Rancangan Perangkat Keras

1. Telur itik, objek yang akan diteliti

2. LED : sebagai sumber cahaya

3. Ruang gelap, ruang yang akan ditempatkan kamera untuk pengambilan gambar

4. Camera $\mathrm{Pi}$, perangkat yang akan digunakan untuk pengambilan gambar digital untuk diproses selanjutnya di Raspberry Pi

5. Papan Raspberry $\mathrm{Pi}$, tempat berjalannya perangkat lunak untuk pemroses data

6. Display / monitor LCD , perangkat untuk menampilkan hasil dari proses pengolahan citra digital.
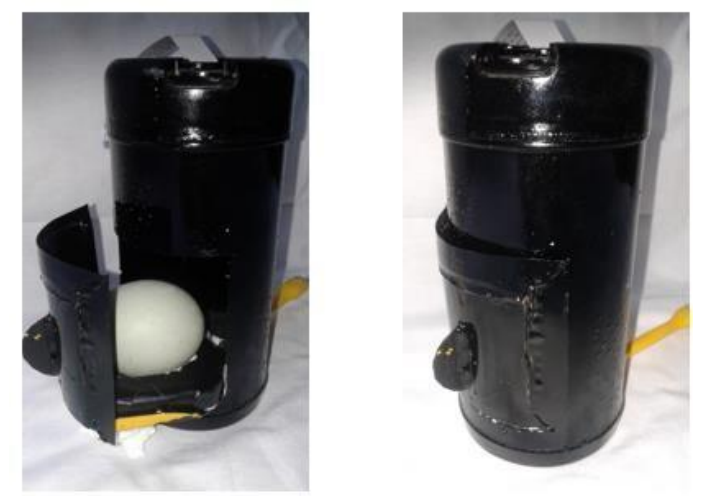
Pada Gambar 3.2 menunjukan tampilan tabung untuk peneropongan telur itik. Sumber cahaya menggunakan LED USB light, posisi objek telur berada ditengah, kamera berada diatasnya dengan jarak $\pm 5 \mathrm{~cm}$ dari objek telur.

\section{B. Kerangka Kerja Perangkat Lunak}

Pada bagian ini dijelaskan langkah demi langkah bagian-bagian penting pembentuk sistem ini. Penerapan pengolaha citra digital dan pengenalan pola. Dibagian ini pula menjelaskan diagram alir dan pandangan umum tentang klasifikasi fertilitas telur itik. Diagram alir yang diusulkan seperti Gambar 5 .

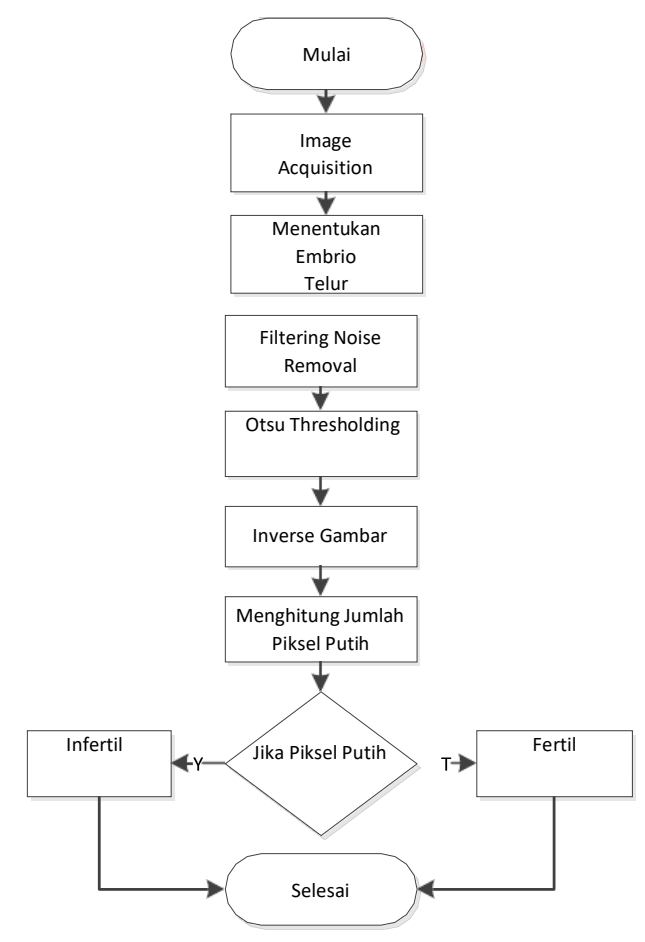

Gambar 3. 3: Diagram untuk klasifikasi telur

\section{Akuisisi Gambar}

Pada proses image acquisition penggunaan perangkat keras yang digunakan. Dimana algoritma pengambilan gambar embrio telur itik dipersiapkan.

Dalam gambar 6 algoritma pengambilan gambar dimulai dengan inisialisai semua perangkat. Pertama ketikan sistem diaktifkan akan mengambil video ketika tombol Proses ditekan maka sistem akan mengambil satu frame gambar yang akan diproses. Kamera yang digunakan yaitu Camera Pi, gambar yang diambil 640 x 480 piksel. Pada proses ini gambar yang diambil yaitu gambar original RGB. 


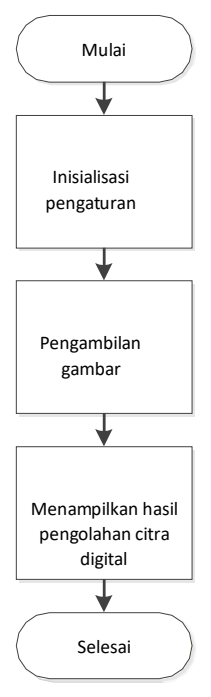

Gambar 3. 4: Diagram alir pengambilan gambar

\section{Menentukan Citra Embrio Telur}

Langkah pertama pada tugas pre-processing adalah mencari objek yang akan diteliti yaitu embrio telur, dengan teknik mengambil citra yang berwarna merah, karena warna embrio pada citra yang diambil berwarna merah. Dengan teknik masking yaitu citra yang selain warna merah akan dirubah atau ditutup dengan warna hitam. Penentuan warna merah dilakukan dengan penentuan nilai bawah dan nilai atas dari nilai RGB citra tersebut. Masking menggunakan operator bitwise and dimana akan bernilai 1 jika kedua input bernilai 1 .

\section{E. Filter dan Penghapusan Derau}

Pada bagian ini untuk meng-crop objek dan menghilangkan noise, menggunakan teknik filter sebagaiteknik untuk menghilangkan noise dan meningkatkan kualitas gambar. Gambar yang diambil awalnya berbentuk RGB selanjutnya di filter dengan teknik median filter, median filter terbukti lebih baik dibandingkan dengan algoritma yang lain untuk menghilangkan noise karena mampu mempertahankan garis tepi dan mudah diimplementasikan (Chandel and Gupta, 2013). Setelah itu gambar dikonversi ke bentuk greyscale untuk menghasilkan gambar berkualitas baik pada proses thresholding.

\section{F. Threshold}

Pada langkah ini untuk mengkonversi gambar ke gambar binary digunakan metode Otsu dan diinverse untuk mendapatkan nilai piksel putih, metode Otsu telah banyak digunakan dikarenakan lebih sederhana dan memberikan kualitas yang baik (Vala and Baxi, 2013).

Metode Otsu melakukan penyeleksian nilai threshold dari histrogram citra abu-abu. Metode penyeleksian nilai threshold dilakukan dengan memakai pendekatan statistika. Nilai threshold dipilih dari nilai warna keabuan yang terletak pada interval histogram dimana nilai warna keabuan tersebut memaksimalkan nilai fungsi : 


$$
\begin{aligned}
& \eta(k)=\sigma_{B}^{2}(k) / \sigma_{T}^{2} \\
& \text { Dan }{ }^{L} \\
& \sigma_{T}^{2}=\sum_{i=1}\left(i-\mu_{T}\right)^{2} P_{i} \\
& \mu_{T}=\mu(L)=\sum_{i=1} i P_{i} \\
& \mu(k)=\sum_{i=1}^{k} i P_{i} \\
& \omega(k)=\sum_{i=1}^{k} P_{i} \\
& P_{i}=n_{i} / N, P_{i} \geq 0, \sum_{i=1}^{L} P_{i}=1
\end{aligned}
$$

Piksel pada citra direpresentasikan ke dalam derajat keabuan $L[1,2, \ldots, L]$. Jumlah piksel dengan derajat keabuan $i$ dinotasikan dengan $n_{i}$ dan jumlah keseluruhan piksel dengan $N=n_{1}+n_{2}$ $+\ldots+n_{i} . P_{i}$ adalah representasi histogram, $k$ adalah nilai threshold.

\section{G. Inverse dan Hitung Pixel Putih}

Setelah itu gambar diinverse atau dirubah nilainya ke nilai sebaliknya. Untuk merubah gambar objek embrio menjadi warna putih sebaliknya warna latar akan menjadi hitam.

Untuk mendeteksi embrio telu dengan cara menghitung sebaran piksel putih yang bernilai biner 1, hasil dari proses sebelumnya yaitu segmentasi menggunakan metode otsu. Yaitu nilai dari matrik yang bernilai biner 1 akan dijumlahkan sehingga akan diketahui jumlah sebaran piksel putih. Penelitian sebelumnya dilakukan untuk mendeteksi kotoran pada telur (Dehrouyeh et al., 2010).

\section{H. Klasifikasi}

Pada tahapan ini nilai dari tahapan sebelumnya akan dibandingkan dengan rentang nilai. Rentang nilai piksel ditentukan dari hasil pengujian telur yang sudah dideteksi dan ditentukan telur dengan kriteria fertil daninfertil.

\section{Algoritma Featrure Extraction}

Pada tahap pertama penentuan objek embrio dengan mengambil objek berdasar warna yaitu warna merah, warna lain menjadi latar belakang selanjutnya citra dipertajam dengan median blur selanjutnya dirubah ke citra abu-abu dan selanjutnya di konversi ke citra biner dengan metode otsu thresholding dan diinverse untuk merubah warna objek menjadi warna putih untuk dihitung sebaran piksel putihnya, setelah itu dibandingkan untuk menentukan fertilitasnya yaitu fertil dan infertile, tahapan algoritma ditampilkan pada Tabel 3.1.

Tabel 3. 1: Algoritma klasifikasi telur

\begin{tabular}{cl}
\hline NO. & \multicolumn{1}{c}{ Algoritma } \\
\hline 1 & Menentukan objek embrio \\
\hline 2 & Sharpening gambar (Median blur) \\
\hline 3 & Konversi citra ke citra abu-abu (grey scale) \\
\hline 4 & $\begin{array}{l}\text { Konversi citra abu-abu ke citra biner }(\text { Otsu } \\
\text { Thresholding) }\end{array}$ \\
\hline 5 & Inverse citra \\
\hline 6 & Menghitung total piksel putih dari citra biner \\
\hline 7 & $\begin{array}{l}\text { Membandingkan jumlah piksel putih gambar } \\
\text { fertile dan infertil }\end{array}$ \\
\hline 8 & Menentukan fertilitas telur fertil atau infertil \\
\hline
\end{tabular}

\section{J. Metode Pemilihan Sampel}

Metode sampling atau pemilihan sampel pada penelitian ini menggunakan Non Probability Sample (Selected Sample). Sedangkan teknik yang digunakan adalah Quota sampling, yaitu cara pengambilan sampel berdasarkan jumlah yang telah ditentukan. Menurut (Gay \& Diehl, 1992) berpendapat bahwa sampel haruslah sebesar- besarnya. Pendapat ini mengasumsikan bahwa 
semakin banyak sampel yang diambil maka akan semakin representatif dan hasilnya dapat digeneralisir. Namun ukuran sampel yang diterima akan bergantung pada jenis penelitiannya..

a. Jika penelitian bersifat deskriptif, maka sampel minimumnya adalah 100 subjek

b. Jika penelitian korelasional, sampel minimumnya adalah 50 subjek

c. Jika penelitian kausal perbandingan, sampelnya sebanyak 30 subjek per-grup

d. Jika penelitian eksperimental, sampel minimumnya adalah 15 subjek per grup.

Pada penelitian ini proses pengambilan data identifikasi akan dilakukan dengan melakukan percobaan pada beberapa kondisi tertentu sehingga tergolong ke dalam penelitian eksperimental. Percobaan atau eksperimen yang akan dilakukan pada setiap kondisi berjumlah 20 kali percobaan.

\section{K. Pengujian}

Penarikan kesimpulan adalah hasil akhir dari analisis yang dapat digunakan untuk mengambil tindakan. Hasil penarikan kesimpulan yang pertama adalah pemilihan teknik pengolahan citra digital sebagai metode penelitian berdasarkan pada data studi pustaka / literatur yang menunjukan bahwa metode tersebut memiliki tingkat akurasi yang paling tinggi diantara metode identifikasi lainnya. Dan penarikan kesimpulan yang kedua adalah tingkat akurasi proses identifikasi sistem berdasarkan data hasil pengujian. Tingkat akurasi pada penelitian ini dihitung dengan rumus :

$$
\text { Akurasi }(\%)=\frac{\text { Jumlah yang diklasifikasi secara benar }}{\text { Total sampel testing yang di uji }} \times 100 \%
$$

\section{HASIL DAN PEMBAHASAN}

Berdasarkan hasil pengambilan data pada kondisi telur itik sebanyak 20 kali, Jumlah piksel putih terbesar untuk kondisi telur infertil adalah 30 piksel. Maka nilai batas jumlah piksel putih pada penelitian ini adalah 30 piksel dengan ketentuan sebagai berikut :

A. Jika nilai piksel putih $\leq 30$ maka hasil identifikasi menyatakan bahwa citra uji Infertil, dan

B. jika nilai piksel putih > 30 maka hasil identifikasi menyatakan bahwa citra uji fertil.

\section{a. Tampilan Perangkat Lunak}

Interface atau tampilan sistem dilakaukan untuk mempermudah pengguna sistem atau (user), rancangan interface ditunjukan pada gambar 7 .

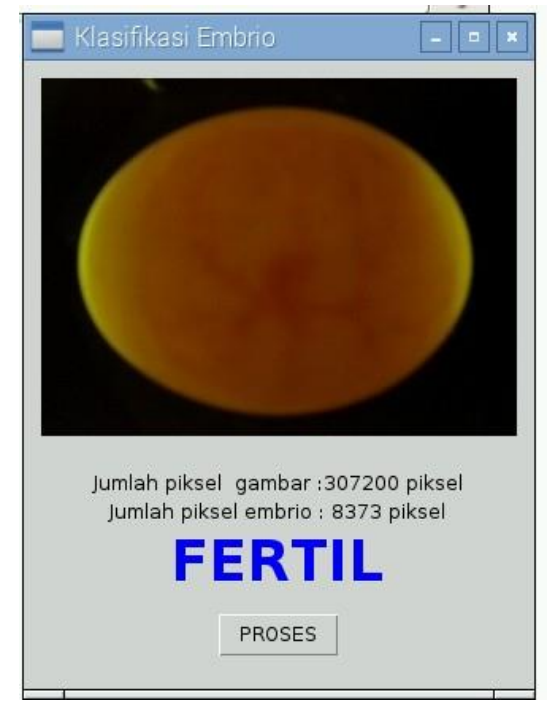

Gambar 4. 1: Tampilan Program

\section{b. Perancangan Sistem}

Perancangan sistem sesuai dengan delapan tahapan algoritma yang dibangun. Gambar 8 (a) adalah citra hasil pengambilan gambar yang akan diproses, gambar 8 (b) citra hasil pengambilan objek embrio, gambar 8 (c) citra hasil proses filtering, gambar 8 (d) citra hasil proses greyscale, gambar 8 (e) citra hasil proses Otsu thresholding, gambar 8 (d) citra hasil proses inverse. 


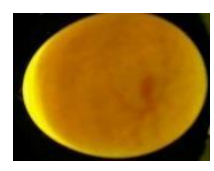

a

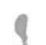

d

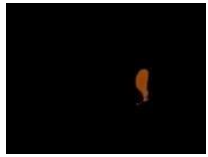

b

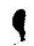

e

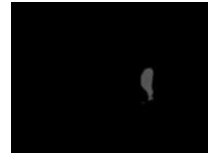

C

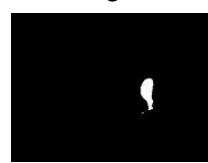

f

Gambar 4. 2: Hasil tahapan proses citra digital

\section{c. Pengujian Sistem}

Pengujian akurasi sistem dilakukan pada dua jenis kondisi untuk mendapatkan hasil pengujian yang variatif. Jumlah percobaan pada setiap kondisi dilakukan sebanyak 20 kali percobaan.

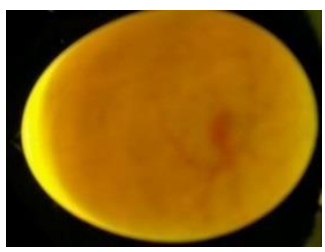

a

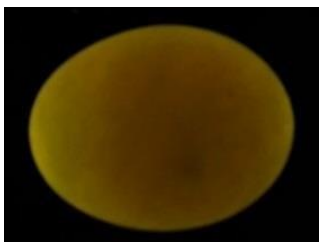

b

Gambar 4. 3: (a) Telur Fertil, (b)Telur Infertil Tabel 4. 1: Rangkuman hasil pengujian klasifikasi telur

\begin{tabular}{|c|l|l|c|}
\hline NO & Kondisi Telur & Deskripsi & Akurasi \\
\hline 1 & Fertil & Telur Fertil & $95 \%$ \\
\hline 2 & Infertil & Telur Infertil & $90 \%$ \\
\hline
\end{tabular}

\section{KESIMPULAN DAN RENCANA KEDEPAN}

\section{A. Kesimpulan}

Berdasarkan hasil perumusan permasalahan, studi pustaka, tinjauan penelitian, tinjauan obyek penelitian dan metodologi penelitian dalam penerapan sistem klasifikasi telur itik dengan menggunakan Raspberry $\mathrm{Pi}$, maka dapat disimpulkan bahwa dengan adanya alat ini untuk mengklasifikasi fertilitas telur itik menggunakan Raspberry Pi mampu mengklasifikasi dengan akurasi untuk telur infertile $\mathbf{9 5 \%}$ dan telur fertile $\mathbf{9 0 \%}$ dibandingkan cara manual mencapai akurasi $90 \%$.

\section{B. Rencana Kedepan}

Setelah melakukan penelitian hasil yang didapatkan belum maksimal, maka perlu ditingkatkan hasilnya dengan cara penggunaan kamera yang lebih tinggi nilai pikselnya, perancangan hardware yang lebih baik dan proses klasifikasi menggunakan metode kecerdasan tiruan.

\section{REFERENSI}

Chandel, R. and Gupta, G. (2013) 'Image Filtering Algorithms and Techniques : A Review', 3(10), pp. 198-202.

Dehrouyeh, M. H. et al. (2010) 'Grading and Quality Inspection of Defected Eggs Using Machine Vision', 17(2005), pp. 23-30.

Holambe, P. S. N. and Kumbhar, P. G. (2016) 'Comparison between Otsu 's Image Thresholding Technique and Iterative Triclass', 33(2).

Ibrahim, R. et al. (2012) 'Egg's Grade Classification and Dirt Inspection Using Image Processing Techniques', II, pp. 4-7.

Senthilkumar, G., Gopalakrishnan, K. and Kumar, V. S. (2014) 'EMBEDDED IMAGE CAPTURING SYSTEM USING RASPBERRY PI SYSTEM Abstract ':, 3(2), pp. 213-215. 
Shilpashree, K. ., Lokesha, H. and Shivkumar, H. (2015) 'Implementation of Image Processing on Raspberry Pi’, 4(5), pp. 199-202. doi: 10.17148/IJARCCE.2015.4545.

Vala, H. J. and Baxi, P. A. (2013) 'A Review on Otsu Image Segmentation Algorithm', 2(2), pp. 387-389.

Zhu, Z. and Ma, M. (2011) 'The identification of white fertile eggs prior to incubation based on machine vision and least square support vector machine', 6(12), pp. 2699-2704. doi: 10.5897/AJAR11.509. 